\title{
Water distribution system coupled to a sustainable purification plant for low- income communities in México
}

\section{Red de distribución de agua acoplada a una purificadora sustentable para comunidades de bajos recursos en México}

TORRES-LÓPEZ, José Manuel†, CRUZ GÓMEZ, Marco Antonio*, MEJÍA PÉREZ, José Alfredo, LÓPEZ AGUILAR, Genaro Roberto

Benemérita Universidad Autónoma de Puebla; Facultad de Ingeniería, Grupo de Tribología and Transporte, Cuerpo Académico 189 (Prevención de Desastres and Desarrollo Sustentable, Tribología, BUAP), Edificio de Posgrado, Primer nivel, Cubículo Núm. 16, Blvd. Valsequillo esq. Av. San Claudio, Ciudad Universitaria, Col. San Manuel, CP. 72570, Puebla

ID $1^{\text {st }}$ Author: José Manuel, Torres-López / ORC ID: 0000-0002-3372-6241, Researcher ID Thomson: AAE--7203-2021, CVU CONACYT ID: 1103524

ID $1^{\text {st }}$ Co-author: Marco Antonio, Cruz-Gómez / ORC ID: 0000-0003-1091-8133, Researcher ID Thomson: S-3098-2018, CVU CONACYT ID: 349626

ID $2^{\text {nd }}$ Co-author: José Alfredo, Mejía-Pérez / ORC ID: 0000-0002-4090-8828, Researcher ID Thomson: G-3354-2019

ID $3^{\text {rd }}$ Co-author: Genaro Roberto, López-Aguilar/ ORC ID: 0000-0003-0140-7163, Researcher ID Thomson: AAN6708-2021, CVU CONACYT ID: 504343

DOI: $10.35429 / J U S D .2021 .20 .7 .31 .38$

Received: March 10, 2021; Accepted June 30, 2021

\section{Abstract}

The National Water Commission (CONAGUA), determined that in Mexico approximately $10 \%$ of the population does not have water in their homes. In addition, Mexico is the country that consumes the most bottled water in the world, although there are communities that do not have water for their consumption. This research proposed a drinking water distribution network coupled to a disinfection plant for low-income communities in Mexico. It was carried out using a mixed methodology, applying quantitative techniques to find out the number of people without drinking water service in Mexico and qualitative ones to determine the best option of materials, purification method and type of supply. However, certain parameters must be met in the communities such as the maximum number of 1200 inhabitants for this option to be viable. This research served as a base project for implementation in remote communities and that will be proposed to government agencies and projects.

Drinking wáter, Distribution, Nanofiltration

\begin{abstract}
Resumen
La Comisión Nacional del Agua (CONAGUA), determinó que en México aproximadamente el 10\% de la población no tiene agua entubada en sus hogares. Además, México es el país que más consume agua embotellada en el mundo, no obstante, existen comunidades que no cuentan con agua para su consumo. Esta investigación propuso una red de distribución de agua potable acoplada a una planta de desinfección para comunidades de bajos recursos en México. Se realizó mediante una metodología mixta, aplicando técnicas cuantitativas para saber el número de personas sin servicio de agua potable en México y cualitativas para determinar la mejor opción de materiales, método de purificación y tipo de suministro. Sin embargo, se deben cumplir ciertos parámetros en las comunidades como el número máximo de 1200 habitantes para que esta opción sea viable. Esta investigación sirvió como proyecto base para implementación en comunidades apartadas y que se buscará proponer a dependencias y proyectos de gobierno.
\end{abstract}

Agua potable, Distribución, Nanofiltración

Citation: TORRES-LÓPEZ, José Manuel, CRUZ GÓMEZ, Marco Antonio, MEJÍA PÉREZ, José Alfredo, LÓPEZ AGUILAR, Genaro Roberto. Water distribution system coupled to a sustainable purification plant for low-income communities in México. Journal of Urban and Sustainable Development. 2021. 7-21: 31-38

\footnotetext{
*Correspondence to the author (e-mail: mangcruz@live.com)

$\dagger$ Researcher contributing as first author
} 


\section{Introduction}

Water is an essential liquid for life and the development of society, it is used for industrial, domestic, and human consumption purposes. World Health Organization [WHO]. (2013) and Boadi, N. et al. (2020). More than 7,000 million people live in the world today. United Nations [UN]. (2016). However, 2 billion people (approximately $28 \%$ of the world population) lack access to drinking water services since population growth has accelerated and the technical difficulties to carry out this work have increased. United Nations [UN]. (2020). Furthermore, the sources of drinking water have diminished due to anthropogenic effects such as deforestation, human settlements and agriculture. Boadi, N. et al. (2020). Therefore, one of the challenges facing the world today is providing drinking water services to the population. United Nations [UN]. (2020).

In Mexico the population that has this service has increased since 1990 , where $75 \%$ of the population had piped water, until 2015 where more than $90 \%$ have this service. Comisión Nacional del Agua [CONAGUA]. (2018). However, as coverage increases, the water supply becomes more complex. Comisión Nacional del Agua [CONAGUA]. (2019) and López, P. (2019).

Additionally, Mexico is the country that consumes the most bottled water in the world. Paullier, J. (2015). This is because the water travels long distances to reach its destination, which means that it passes through several sections of pipes, which can contaminate the water, carrying impurities in its path. Added to this, many families store water for their homes in places that are not properly cleaned. Therefore, the population in Mexico prefers to consume bottled water before that supplied in their homes, however some communities do not have water to drink.

The objective of this research is to propose a drinking water distribution network coupled with a sustainable disinfection system to supply water for homes and human consumption in communities with a population of maximum 1,200 inhabitants.
It seeks to improve the quality of life of its population with a safe and sustainable water service, for which a disinfection system was proposed that used renewable energy sources for its operation. El Ghzizel, S. et al. (2020). However, to adequately achieve the supply, different factors such as water chemistry, choice of materials for the network and the location of the distribution tank must be taken into account, because by omitting the importance of these factors, the population is exposed to problems of Health. Alvarez, $C$. et al. (2013) and Moskvicheva, E. et al. (2016). In this way, it is possible to supply drinking water to communities in need of this service in Mexico.

\section{Methodology}

This article uses a mixed investigation, applying quantitative and qualitative methods in systematic processes, using books, manuals, articles, and web pages as sources of information. Due to the lack of potable water distribution in low-income areas in Mexico, this research proposed a potable water distribution network coupled with a disinfection system for these communities. The quantitative approach is necessary to obtain the maximum number of inhabitants of the population to supply.

However, the qualitative approach was used to select the type of network distribution, examine the health damage caused by water with inappropriate chemistry for consumption, and determine the advantages of the proposed purification system. In this way, it was possible to propose a water distribution network coupled with a disinfection system for communities with a population of fewer than 1200 inhabitants in Mexico, to improve the quality of life of its population and the development of said communities. Hernández, R. et al. (2010).

\section{Distribution of wáter}

Water for domestic use is transported through a distribution network, which is the union of pipes, special components, and accessories. Its objective is to lead the water from the service tanks to a household outlet or public hydrants. This network must supply drinking water all the time at the pressure, quantity, and quality necessary to satisfy the daily needs of the population. 
The specifications of the water to be considered potable are in the Norma Oficial Mexicana NOM-127-SSA1 current. Comisión Nacional del Agua [CONAGUA]. (2019). Figure 1 shows a diagram of a water supply system.

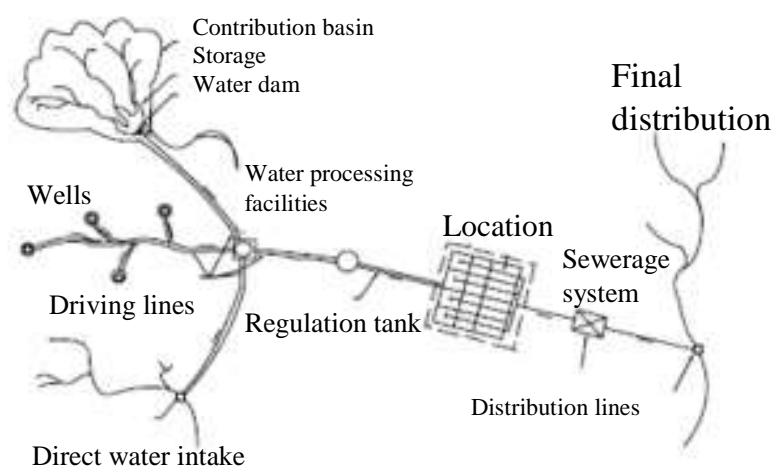

Figure 1 Water distribution network

Comisión Nacional del Agua [CONAGUA].

(2019)

One of the main factors for the design of the distribution network is the choice of pipe material, for this, factors such as durability, corrosion, economy, ease of connection and repair, but especially, the conservation of the water quality. The World Health Organization generated guidelines for the quality of drinking water, where the risks associated with the microbial hazards present in the water are evaluated and the requirements to guarantee the safety of the water are explained, including the minimum procedures and specific reference values, and how those requirements should be applied. World Health Organization [WHO]. (2006). Table 1 shows the advantages and disadvantages of the materials most used in the manufacture of pipes.

\begin{tabular}{|c|c|c|}
\hline Material & Advantage & Disadvantages \\
\hline Steel & $\begin{array}{l}\text { High strength, lighter } \\
\text { than the iron pipe, easy } \\
\text { to transport and install. }\end{array}$ & $\begin{array}{l}\text { It is susceptible to } \\
\text { crushing and presents } \\
\text { corrosion since it is a } \\
\text { metallic material. }\end{array}$ \\
\hline $\begin{array}{c}\text { Iron } \\
\text { Ductile }\end{array}$ & $\begin{array}{l}\text { High service life, it's the } \\
\text { way of welding is } \\
\text { economical, mechanical } \\
\text { resistant, and requires } \\
\text { relatively little } \\
\text { maintenancer }\end{array}$ & $\begin{array}{l}\text { It can suffer electrical or } \\
\text { chemical corrosion, their } \\
\text { weight creates difficulties } \\
\text { in handling and they are } \\
\text { not manufactured in } \\
\text { Mexico, therefore they } \\
\text { imply costs and import } \\
\text { procedures. }\end{array}$ \\
\hline PVC & $\begin{array}{l}\text { High resistance to } \\
\text { corrosion, it is a light } \\
\text { and flexible material, it } \\
\text { has good tensile } \\
\text { strength, it is easy to } \\
\text { install and it does not } \\
\text { affect the quality of the } \\
\text { water. }\end{array}$ & $\begin{array}{l}\text { It can be easily damaged } \\
\text { during transport, it reduces } \\
\text { its resistance if it is at } 0^{\circ} \\
\mathrm{C} \text { and the working } \\
\text { pressure must be reduced } \\
\text { if it is at a temperature } \\
\text { higher than } 25^{\circ} \mathrm{C} \text {. }\end{array}$ \\
\hline
\end{tabular}

Table 1 Advantages and disadvantages of pipe materials. Comisión Nacional del Agua [CONAGUA]. (2019)
Therefore, considering the advantages and disadvantages, the material that offers the best conditions according to its advantages and disadvantages is PVC. On the other hand, there are different ways of supplying water to users depending on local conditions, the two main ones are by gravity and by pumping, however, in some cases, a mixed-method can be used. Comisión Nacional del Agua [CONAGUA]. (2019). Currently, most of the works of distribution networks in urban areas are done to improve or expand existing networks. The generation of new works to supply the service to new or isolated places is minimal. Comisión Nacional del Agua [CONAGUA]. (2019).

\section{Distribution network design}

The first factor to consider when designing a distribution network is the source of water to supply the network. Communities may have surface or underground sources of water, therefore a geophysical study is necessary to determine the source of water to supply the distribution network. For underground sources, the water intake from the network must be through a well. On the other hand, for surface sources, the water can be obtained through rivers or springs. On the other hand, it is necessary to identify if the terrain in the area is flat or has irregular heights, which will determine whether the type of distribution of the network will be by gravity or mixed (by gravity and pumping). Therefore, the idea is to locate the distribution tank in a high area, in this way the water can be conducted by gravity to the population. However, a mixed distribution can be used, since the conduction to the tank can be carried out by pumping, subsequently, the water is supplied from the tank to the users using gravity. Comisión Nacional del Agua [CONAGUA]. (2019). Figure 2 shows a diagram of a mixed-type water distribution system.

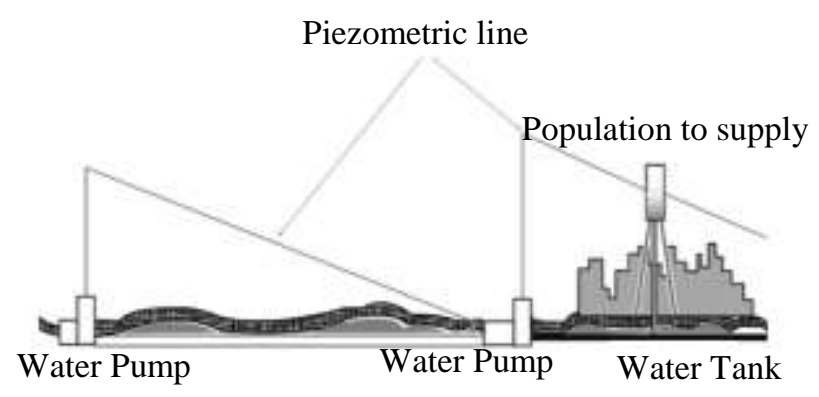

Figure 2 Diagram of a mixed-type water distribution system

Comisión Nacional del Agua [CONAGUA]. (2019)

TORRES-LÓPEZ, José Manuel, CRUZ GÓMEZ, Marco Antonio, MEJÍA PÉREZ, José Alfredo, LÓPEZ AGUILAR, Genaro Roberto. Water distribution system coupled to a sustainable purification plant for lowincome communities in México. Journal of Urban and Sustainable Development. 2021 
The capacity of the tank is based on the maximum daily expenditure and the demands of the area, it can be obtained by graphical or analytical methods. It is important to consider the feeding time of the supply sources to the tank, storing the water in the hours of low demand to distribute it in the hours of high demand.

In addition, a volume of water reserved for emergencies such as network failures or repairs must be taken into account. Comisión Nacional del Agua [CONAGUA]. (2019). To determine the location and layout of the pipe network for the distribution system, a field survey is required.

The design of the conduction and distribution lines must be defined taking into account the existing roads of the community and avoiding crossing private properties. For what is shown in Table 1, a PVC pipe is recommended over the other materials for the distribution network, since this material is light and flexible, resistant to corrosion and stress, presents low friction losses since the inner wall is smooth and does not affect the quality of the water. Comisión Nacional del Agua [CONAGUA]. (2019).

On the other hand, for remote communities, this material is feasible because it is inexpensive, easy to install, and requires less maintenance than other materials. The quality of drinking water is necessary for good health.

The guarantee of the microbial safety of the drinking water supply is based on the application of multiple barriers to avoid or reduce the contamination present in the water to levels that are not harmful to health, for example, nitrate content less than $50 \mathrm{mg} / \mathrm{L}$, chlorine less than $5 \mathrm{mg} / \mathrm{L}$, in addition to the removal of sludge, animal feces, and solid particles. World Health Organization [WHO]. (2006).

To provide safe drinking water service, factors such as water chemistry and corrosion must be taken into account. Kutz, M. (2018), Alvarez, C. et al. (2013) and Moskvicheva, E. et al. (2016).

\subsection{Water chemistry}

Drinking water contains complex chemistry, which has an impact on both plumbing, human ingestion, and environmental implications. Factors such as pH, alkalinity, dissolved inorganic carbon, hardness, chloride, sulfate, inhibitors, disinfectants, bacteria, dissolved oxygen, solids, and turbidity are essential to determine the reactions caused by water chemistry such as corrosion and precipitation. Kutz, M. (2018).

On the other hand, the mentioned factors can interact with each other, which demonstrates the complexity of the processes that can occur in drinking water. Therefore, it is very important to calculate the chemical characteristics of the water before choosing the materials used in the distribution networks. Álvarez, C. et al. (2013).

\subsection{Corrosion}

Water has a corrosive nature, it frequently contains nitrate $\left(\mathrm{NO}_{3}\right)$, which can cause damage to the health of the inhabitants of a population. On the other hand, water carries corrosion particles in the pipes, especially in metal pipes, which corrode and release solid particles carried by the water. In the case of plastic pipes, this phenomenon decreases drastically, but particles of the pipe material are still dragging along. Alvarez, C. et al. (2013).

Effectively protecting the pipeline against corrosion is necessary for a long and safe service life of pipeline systems, since in addition to being harmful to humans, corrosion in pipes causes large-scale contamination in the lithosphere and the hydrosphere. Corrosion of materials depends on different factors such as water chemistry, temperature, and building materials. On the other hand, materials can develop thin films, which can reduce the internal diameter of the pipe, causing blockages and blockages. Moskvicheva, E. et al. (2016).

\subsection{Water for human consumption}

The inadequate distribution of drinking water throughout the world causes millions of people to be frequently exposed to dangerous microbiological contaminants such as sludge and solid particles, and chemicals, for example, nitrate concentrations greater than $50 \mathrm{mg} / \mathrm{L}$ in water.

TORRES-LÓPEZ, José Manuel, CRUZ GÓMEZ, Marco Antonio, MEJÍA PÉREZ, José Alfredo, LÓPEZ AGUILAR, Genaro Roberto. Water distribution system coupled to a sustainable purification plant for lowincome communities in México. Journal of Urban and Sustainable Development. 2021 
Which does not comply with what is recommended by the WHO in the guidelines for the quality of drinking water. World Health Organization [WHO]. (2006). For this reason, chemical and physical methods have been developed for water purification. In chemical methods, substances capable of disinfecting are added, such as chlorine and ozone. However, these substances can generate secondary reactions, which can be dangerous to health. Existing physical methods such as ultraviolet radiation, membrane separation, and thermal disinfection are often expensive and generally do not meet the desired level of disinfection. $E l$ Ghzizel, S. et al. (2020).

Well-drawn groundwater is commonly considered safe to drink. However, its quality depends on different factors such as climatic changes, types of soil, surfaces, and nature of the rocks through which the water moves, therefore it is recommended that the well water be treated before drinking it. Boadi, N. et al. (2020).

\section{Drinking water purifier}

A study carried out at the Al Annouar institute in Sidi Taibi in Morocco showed the first water purification plant, where nanofiltration is used coupled with an electrochemical disinfection system that is powered by photovoltaic and wind energy. This plant was designed to supply drinking water to the 1,200 students of the $\mathrm{Al}$ Annouar institute. El Ghzizel, S. et al. (2020). Figure 3 shows the schematic of the Sidi Taibi plant.

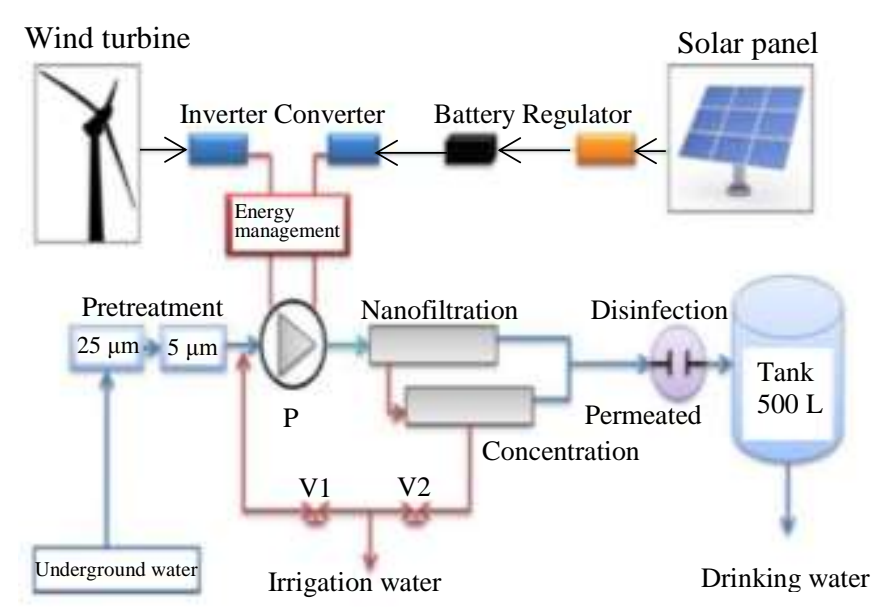

Figure 3 Scheme of the Sidi Taibi purification plant El Ghzizel, S. et al. (2020).
The process is carried out using groundwater, which is pumped to the plant through inlet pipes. At the beginning of the process, the water is transported to the pretreatment behavior, which is made up of 2 filters, the first $25 \mu \mathrm{m}$ and the second $5 \mu \mathrm{m}$, these are connected in series and allow the removal of sludge and fine particles from the water. El Ghzizel, S. et al. (2020). These filters are made of polypropylene microfibers bonded by thermal action.

Subsequently, the pretreated water is transported to the nanofiltration compartment, which consists of two spiral membranes of the type: polyamide thin-film compound, its operating characteristics are shown in table 2. El Ghzizel, S. et al. (2020).

\begin{tabular}{|l|c|}
\hline \multicolumn{1}{|c|}{ Parameter } & Value \\
\hline Maximum operating temperature $\left({ }^{\circ} \mathrm{C}\right)$ & 45 \\
\hline Maximum operating pressure $($ bar $)$ & 41 \\
\hline PH range, continuous operation & $3-10$ \\
\hline Maximum feed flow $\left(\mathrm{m}^{3} / \mathrm{h}\right)$ & 15.9 \\
\hline Maximum feed sediment density index (SDI) & 5 \\
\hline
\end{tabular}

Table 2 Characteristics of the membranes used for nanofiltration

El Ghzizel, S. et al. (2020)

At the end of the nanofiltration, the water is disinfected through an electrochemical process without the need for additives. $E l$ Ghzizel, S. et al. (2020). Electrochemical disinfection is a process in which electrons supplied by direct electrical current react with ions and molecules in the water. Global Aquaculture Alliance. (2020). In addition, this process oxidizes chloride, which generally occurs in water, to free chlorine. El Ghzizel, S. et al. (2020). The characteristics of the electrochemical disinfection system are shown in Table 3.

\begin{tabular}{|c|c|}
\hline Parameter & Value \\
\hline Power input (V) & 220 \\
\hline $\begin{array}{l}\text { Raw Water Required Chloride Range } \\
(\mathrm{mg} / \mathrm{L})\end{array}$ & $10-250$ \\
\hline Maximum operating flow (L/h) & 400 \\
\hline Minimum operating flow $(\mathrm{L} / \mathrm{h})$ & $\begin{array}{l}\text { Depends on the } \\
\text { current supply }\end{array}$ \\
\hline Power Consumption Range (W) & $100-700$ \\
\hline Water temperature range $\left({ }^{\circ} \mathrm{C}\right)$ & $4-25$ \\
\hline $\begin{array}{l}\text { Minimum conductivity of raw wáter } \\
(\mu \mathrm{s} / \mathrm{cm})\end{array}$ & 300 \\
\hline Maximum ambient temperatura $\left({ }^{\circ} \mathrm{C}\right)$ & 50 \\
\hline
\end{tabular}

Table 3 Characteristics of the electrochemical disinfection process

El Ghzizel, S. et al. (2020) 
Finally, the purified water is led to a storage tank and distribution begins. El Ghzizel, S. et al. (2020).

\section{Results}

Table 4 presents the characteristics of the groundwater sample and water after the permeate.

\begin{tabular}{|c|c|c|c|}
\hline & $\begin{array}{l}\text { Underground } \\
\text { water }\end{array}$ & Permeated & $\begin{array}{c}\text { Ion rejection } \\
(\%)\end{array}$ \\
\hline$K^{+}(m g / L)$ & 7.04 & 1.5 & 78.6 \\
\hline $\begin{array}{l}\mathrm{Na}^{+} \\
(\mathrm{mg} / \mathrm{L})\end{array}$ & 4.95 & 0.77 & 84.4 \\
\hline $\begin{array}{l}M g^{2+} \\
(m g / L)\end{array}$ & 36.01 & 1.3 & 96.3 \\
\hline $\begin{array}{l}\mathrm{Ca}^{2+} \\
(\mathrm{mg} / \mathrm{L})\end{array}$ & 112.9 & 8 & 92.9 \\
\hline $\begin{array}{l}\mathrm{HCO}_{3}^{-} \\
(\mathrm{mg} / \mathrm{L})\end{array}$ & 377.3 & 29 & 92.3 \\
\hline $\begin{array}{l}\mathrm{NO}_{3}^{-} \\
(\mathrm{mg} / \mathrm{L})\end{array}$ & 68.7 & 14 & 79.6 \\
\hline $\begin{array}{l}\mathrm{Cl}^{-} \\
(\mathrm{mg} / \mathrm{L})\end{array}$ & 25 & 2 & 96 \\
\hline $\begin{array}{l}\mathrm{SO}_{4}{ }^{-} \\
(\mathrm{mg} / \mathrm{L})\end{array}$ & 35.01 & 1.2 & 96.5 \\
\hline $\begin{array}{l}\text { Conductivity } \\
(\mu \mathrm{s} / \mathrm{cm})\end{array}$ & 856 & 90 & 89 \\
\hline
\end{tabular}

Table 4 Characteristics of the feed water, permeate, and ion rejection

El Ghzizel, S. et al. (2020)

Its great efficiency is because the nanofiltration membrane rejects the charged particles, in this way it can extract a large number of components from the water. On the other hand, electrochemical disinfection has advantages compared to other methods; since it does not require storage, maintenance and transport, in addition, its effect can be adjusted to the required demand. El Ghzizel, S. et al. (2020).

The Sidi Taibi plant works through a permeate flow rate of up to $400 \mathrm{~L} / \mathrm{h}$, with a pressure of 5 bar and a recovery percentage of $75 \%$; the energy it consumes is $0.2 \mathrm{KWh} / \mathrm{m}^{3}$. On the other hand, the quality of the permeate meets the required standards due to the low concentration of nitrate $(14 \mathrm{mg} / \mathrm{L})$, and the WHO recommends a standard of $(50 \mathrm{mg} / \mathrm{L})$. El Ghzizel, S. et al. (2020).

In addition, using alternative energies allows satisfying the electricity demand for this process, which ensures the disinfection of the water, regardless of the weather conditions. $E l$ Ghzizel, S. et al. (2020).

\section{Discussion of results}

The proposed distribution network recommends the use of PVC as the material of the pipes since this material is light, flexible, easy to install, and does not affect the quality of the water, however, other materials can be used in communities where PVC is not feasible either because of the type of soil, water chemistry or environmental conditions.

On the other hand, the type of distribution recommended is by gravity, this is the most reliable distribution method because the pressure remains sufficient and constant in the network, however, if the terrain does not present great heights, a distribution by pumping or pumping can be applied. mixed. Comisión Nacional del Agua [CONAGUA]. (2019).

The water purification process used at the Sidi Taibi plant can be coupled to supply communities with a lack of purified water, as the production of water would be sufficient to meet the needs of a population of fewer than 1,200 inhabitants. The purification plant works through a permeate flow rate of up to $400 \mathrm{~L} / \mathrm{h}$, with a pressure of 5 bar and a recovery percentage of $75 \%$; the energy it consumes is $0.2 \mathrm{KWh} / \mathrm{m}^{3}$. El Ghzizel, S. et al. (2020).

The amount of water produced is adequate since men and women over 14 years of age should consume 2.5 and 2 liters of water a day, respectively (including beverages of all kinds and water present in food). Instituto Mexicano del Seguro Social [IMSS]. (2013). Therefore, for a population of 1,200 inhabitants, this plant can produce up to 8 liters of water per day per inhabitant, enough for drinking and cooking.

In addition, in the area of sustainable development, the proposed network seeks to conserve natural resources and the environment; using renewable energy for its operation, thinking about the natural environment. On the other hand, in the area of sustainable development, it seeks to satisfy the need for drinking water in the communities of Mexico, taking into account the social, economic, and environmental spheres. In the social sphere, it seeks to improve the quality of life of the population of low-income communities. 
In addition, government investment is sought so that the economy of the needy population is not affected. Finally, by using renewable energies such as solar and wind, it allows the purification process to be carried out far from the electricity supply network, which is extremely favorable for the production of drinking water in rural areas. El Ghzizel, S. et al. (2020).

\section{Conclusions}

In Mexico, $10 \%$ of the population does not have drinking water services in their homes. Therefore, a distribution network coupled with a sustainable water purification plant was proposed for communities with less than 1200 inhabitants.

For the design of the network, the proposal is recommended to use PVC as a material for the pipes, however other materials can be used in communities where PVC is not feasible. In addition, it is necessary to identify the source of water, whether surface or underground, later the water is transported to a regulation tank that supplies the water to the houses using gravity or pumping. The design of the water conduction lines must be carried out taking into account the existing roads within the locality. Comisión Nacional del Agua [CONAGUA]. (2019).

The purifier attached to the network uses the process of nanofiltration and electrochemical disinfection. El Ghzizel, S. et al. (2020). This process can be implemented for communities in Mexico with a population of fewer than 1200 inhabitants that need water for their consumption. However, as it is a proposal that uses innovative technologies for its process, government investment is required to be able to implement it in the future.

On the other hand, the cost of the distribution network may vary according to different factors such as; the community topography, number of inhabitants, number of dwellings to be supplied, materials to be used, and type of distribution source, however, the study of the proposed water disinfection system does not stipulate a cost estimate.
However, considering that the distribution network was proposed for a maximum of 1,200 inhabitants and that CONAGUA invests approximately 750 dollars per inhabitant for the realization of water distribution networks, we can estimate an approximate maximum cost of 900,000 dollars with a variation of $20 \%$, indirect costs of the concession to exploit, use or take advantage of national waters, in addition to topographic and geotechnical studies, must be attached to this approximation. On the other hand, to estimate the costs of the water disinfection system, the price of similar equipment is between 5,000 and 8,000 dollars.

However, the objective of this study is to carry out the analysis and development of technology to support sectors that need drinking water, therefore, this project is non-profit, therefore, the economic study for a specific region will be a reason for subsequent studies by the approach to government agencies such as CONAGUA.

In this way, it is intended that this system be applied in low-income communities in Mexico that require water for their homes and consumption, improving their quality of life and the development of low-income communities, in addition to using renewable energies for their process, is sustainable with the environment.

\section{References}

Alvarez, C., Martínez, V., Vázquez, G., Solache, M., Fonseca, G., \& Trujillo, E. (2013). The corrosive nature of manganese in drinking water. Science of The Total Environment, 447, $10-16$.

https://doi.org/10.1016/j.scitotenv.2013.01.005 q

Boadi, N. O., Saah, S. A., Baa-Poku, F., Mensah, E. A., \& Addo, M. (2020). Safety of borehole water as an alternative drinking water source. Scientific African, 10, e00657. https://doi.org/10.1016/j.sciaf.2020.e00657

Comisión Nacional del Agua [CONAGUA]. (2018). Estadísticas del agua en México. Secretaría de Medio Ambiente y Recursos Naturales. 
Comisión Nacional del Agua [CONAGUA]. (2019). Manual de agua potable, alcantarillado y saneamiento "diseño de redes de distribución de agua potable". Subdirección general de agua potable, drenaje y saneamiento.

El Ghzizel, S., Zeggar, H., Tahaikt, M., Tiyal, F., Elmidaoui, A., \& Taky, M. (2020). Nanofiltration process combined with electrochemical disinfection for drinking water production: Feasibility study and optimization. Journal of Water Process Engineering, 36, 1-7. https://doi.org/10.1016/j.jwpe.2020.101225

Global Aquaculture Alliance. (2020). Tratamiento electroquímico del agua. Global Aquaculture Advocate. Recovered from: https://www.aquaculturealliance.org/advocate/t ratamiento-electroquimico-del-agua-de-ras/

Hernández, R., Fernández, C., \& Baptista, P. (2010). Metodología De La Investigación. Mc Graw Hill.

Instituto Mexicano del Seguro Social [IMSS]. (2013). ¿Cuánta agua debo beber? Recovered from: http://www.imss.gob.mx/salud-enlinea/infografias/cuanta-agua-tomar

Paullier, J. (2015). Por qué México es el país que más agua embotellada consume en el mundo. BBC News Mundo. Recovered from: https://www.bbc.com/mundo/noticias/2015/07/1 50722_mexico_consumo_agua_embotellada_jp

Kutz, M. (2018). Handbook of Environmental Degradation of Materials (3rd ed.). William Andrew.

López, P. (2019). Sin acceso al agua potable, 10 por ciento de mexicanos. Gaceta UNAM. Recovered from:

https://www.gaceta.unam.mx/sin-acceso-alagua-potable-10-por-ciento-de-mexicanos/

Moskvicheva, E. V., Sidyakin, P. A., \& Shitov, D. V. (2016). Method of Corrosion Prevention in Steel Pressure Pipelines in Sewerage Systems. Procedia Engineering, 150, 23812386.

https://doi.org/10.1016/j.proeng.2016.07.317

United Nations [UN]. (2020). Agua. Naciones Unidas. Recovered from: https://www.un.org/es/sections/issues-

depth/water/
United Nations [UN]. (2016). Población. Naciones Unidas Departamento de Asuntos Económicos y Sociales. Recuperado de: https://www.un.org/development/desa/es/keyissues/population.html

World Health Organization [WHO]. (2013). Agua potable salubre y saneamiento básico en pro de la salud. Recovered from: https://www.who.int/water_sanitation_health $/ \mathrm{m}$ dg1/es/

World Health Organization [WHO]. (2013). Agua para la salud: un derecho humano. OMS. Recovered from: https://www.who.int/mediacentre/news/releases /pr91/es/\#:\%7E:text=Ginebra\%2C\%2027\%20d e\%20noviembre\%20de,todos\%20los\%20dem\% C3\%A1s\%20derechos\%20humanos.

World Health Organization [WHO]. (2006). Guías para la calidad del agua potable. Recuperado de: https://www.who.int/water_sanitation_health/d wq/gdwq3_es_fulll_lowsres. 